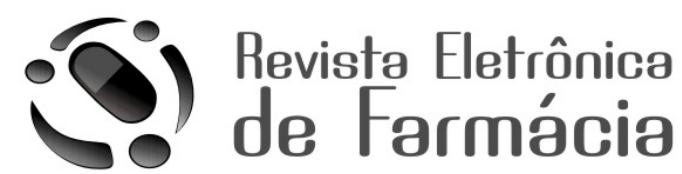

REF - ISSN 1808-0804 Vol. VI (1), 58 - 64, 2009

\title{
EFEITOS COMPORTAMENTAIS INDUZIDOS PELA ADMINISTRAÇÃO DE 6-ISO-ESPECTALINA EM CAMUNDONGOS
}

\author{
Bahavioural effects induced by iso-6- spectaline administration in mice
}

\section{Denne Costa e Silva ${ }^{1}$, Fábio de Oliveira Silva ${ }^{1,2}$, Maria G.V. Silva ${ }^{3}$ e Rivelilson Mendes de Freitas ${ }^{4, *}$}

\author{
${ }^{1}$ Curso de Farmácia, Faculdade Católica Rainha do Sertão. \\ ${ }^{2}$ Doutorando em Química, Departamento de Química Orgânica e Inorgânica da Universidade Federal do \\ Ceará - UFC. \\ ${ }^{3}$ Professora Adjunta do Departamento de Química Orgânica e Inorgânica da UFC. \\ ${ }^{4}$ Professor Adjunto do Departamento de Fisiologia e Farmacologia da Universidade Federal do Paiuí - \\ UFPI. ${ }^{\star}$ Rua Cícero Eduardo, s/n, Junco, Picos, PI, 64.600-000, Brazil. Phone/Fax: 55-(89)-3422-4826.
}

Autor para correspondência: rivelilson@ufpi.br

Recebido em 11/02/2009 - Aceito em 28/02/2009

RESUMO: O presente estudo visa investigar os efeitos comportamentais do alcalóide piperidínico, 6-isoespectalina (SPEC), isolado das folhas de Senna spectabilis (Schrad) var. excelsa em camundongos. Os efeitos de SPEC foram demonstrados utilizando os testes de campo aberto e nado forçado em camundongos. No teste de campo aberto, após a administração de SPEC nas doses $(1,5$ e 3,0 mg/kg, i.p.) houve um aumento significativo na atividade locomotora e no número de rearing e grooming $(p<0,05)$. Nenhuma destas alterações observadas no teste do campo aberto foi revertida pelo prétratamento com flumazenil (2,5mg/kg, i.p.). SPEC nas doses $(1,5$ e $3,0 \mathrm{mg} / \mathrm{kg}$ ) foram testadas também no teste do nado forçado. SPEC nas duas doses produziu uma diminuição no tempo de imobilidade $(p<0,05)$, de forma semelhante à imipramina (controle positivo). As ações de SPEC foram potencializadas quando administrado 15 minutos após a administração de imipramina $(10 \mathrm{mg} / \mathrm{kg})$. No entanto, os efeitos antidepressivos de SPEC, não foram alterados pelo pré-tratamento com a paroxetina, um bloqueador seletivo da recaptação de serotonina. Além disso, os efeitos de SPEC no teste do nado forçado foram totalmente bloqueados pela reserpina que produz a depleção dos níveis das monoaminas. Em conclusão, os resultados do presente trabalho sugerem um possível efeito antidepressivo de SPEC através da modulação do sistema noradrenérgico. As ações farmacológicas de SPEC podem ser produzidas através das alterações no conteúdo de noradrenalina, uma vez que não foram observadas mudanças nos seus possíveis efeitos antidepressivos quando associado ao antagonista benzodiazepínico no teste do campo aberto. Baseado nisso, futuros estudos deverão ser realizados para esclarecer os mecanismos da ação de 6-iso-espectalina no comportamento de camundongos.

PALAVRAS-CHAVES: Planta medicinal, Teste do campo aberto, Teste do nado forçado, Comportamento, Camundongos.

ABSTRACT: This study aims to investigate the behavioral effects of the alkaloid piperidine, iso-6spectaline (SPEC), isolated from the leaves of Senna spectabilis (Schrad) var. excelsa in mice. The effects of SPEC were demonstrated using the open field and forced swimming tests in mice. In the open field test after the administration of SPEC in doses (1.5 and $3.0 \mathrm{mg} / \mathrm{kg}$, ip) there was a significant increase in locomotor activity and number of rearing and grooming $(p<0.05)$. No one of these changes observed in the open field test was reversed by pretreatment with flumazenil $(2.5 \mathrm{mg} / \mathrm{kg}$, ip). SPEC at doses $(1.5$ and $3.0 \mathrm{mg} / \mathrm{kg}$ ) were tested in the forced swim test. SPEC in both doses produced a decrease in the time of immobility $(p<0.05)$, similar to imipramine (positive control). SPEC actions were enhanced when administered 15 minutes after imipramine administration $(10 \mathrm{mg} / \mathrm{kg})$. However, the possible effects 
of antidepressants SPEC were not altered by pre-treatment with paroxetine, a selective blocker of the reuptake of serotonin. Furthermore, the SPEC effects in forced swimming test were completely blocked by reserpine which produces a depletion of monoamines levels. In conclusion, the results of this study suggest a possible effect of antidepressant SPEC through modulation of noradrenergic system. The pharmacological actions of SPEC can be produced through changes in the content of noradrenaline, since no changes were observed in their antidepressant effects when combined with benzodiazepine antagonist in open field test. Based on this, future studies should be conducted to clarify the mechanisms of action of iso-6-spectaline on behavior of mice.

KEYWORD: Medicinal plant, Open field test, Forced swim test, Behavior, Mice.

\section{INTRODUÇÃO}

Senna spectabilis (S. spectabilis) is an arborous species of Fabaceae (subfamily Caesalpiniaceae). In Brazil, many species of Senna are used as ornamental plants due to their beautiful flowers. The $S$. spectabilis is also commonly used in Equador, in traditional medicine for several diseases, alternatively to the conventional allopathic medicine (ABATAM, 1961; CORREIA, 1984; AGRA, 1996). Phenolic compounds present in leaves from $S$. spectabilis have been reported by several pharmacological properties attributed to these species, such as anti-inflammatory, analgesic, laxative, purgative, antimicrobial and antiulcerogenic (COSTA-LOTUFO et al., 2004., VIEGAS et al., 2004). Recently, the leaves from $S$. spectabilis have been reported to be valuable sources of piperidine alkaloid (PIVATTO et al., 2005), and by cytotoxicity of this metabolite against mutant strains of Saccharomyces cerevisiae, which is an indicative of potential antitumor activity (COSTA-LOTUFO et al., 2004). Interestingly, pharmacologic assays with alkaloids demonstrated significant antinociceptive activity and also revealed it as an inhibitor of enzyme acetylcholinesterase (AChE) (HARVEY, 1995, VIEGAS et al., 2008). In addition, antimicrobial and inhibitory properties of superoxide dismutase of macrophages during inflammation (BRINKHAUS et al., 2000; PIVATTO et al., 2005). Due to its ability to interfere with enzymes that act in central nervous system producing antinociceptive action, it is believed that this alkaloid can produce changes in various systems, such noradrenergic, serotonergic, and GABAergic involved in pathophysiology of depression (DUNHAM and MIYA, 1957), contributing to the comprehension of its action mechanism that is still poorly understood.

The leaves from $S$. spectabilis are rich in piperidine alkaloid, such as iso-6-spectaline (SPEC). Alkaloid isolated from several species of medicinal plants is, in general, partly responsible for their biological activities. Recent studies have demonstrated that alkaloids present antinociceptive effect as well as antimicrobial activities (VIEGAS et al., 2008; SHAHVERDI et al., 2008). Other researches on extracted alkaloids have demonstrated an antinociceptive activity as well as an AChE inhibition ability which indicates that SPEC might influence the different neurotransmitters which justify their possible effects on the central nervous system, such as anxiolytic drugs, anticonvulsant and antidepressant.

Therefore, the objective of the present work was to analyze the behavioural effects of acute administration of fraction iso-6-spectaline isolated of leaves from Senna spectabilis in mice. The possible antidepressant actions were studied using the open field and forced swimming tests, in order to evaluate its sedative and antidepressant activities.

\section{MATERIAL AND METHODS}

\section{Collection of plant and experimental procedures}

The plant was collected in September 1998, at the city of Boa Viagem, state of Ceara, Brazil, and was identified by Prof. A.G. Fernandes, from the Department of Biology of the Federal University of Ceara. The voucher specimen is deposited at the Prisco Bezerra Herbarium under the number 33013. Male Swiss mice (25-30 g) from the Animal House of the Faculdade Catolica Rainha do Sertao, Quixada - Ceara, were used throughout the experiments. Animals were housed in standard environmental conditions ( $23 \pm 2{ }^{\circ} \mathrm{C}$, humidity $60 \pm 5 \%, 12 \mathrm{~h}$ light-12 h dark cycle), with free access to a commercial diet and water. Each animal was used only once. Control animals were administered with the suspension of $0.5 \%$ Tween 80 , in distilled water used as vehicle. All experiments were performed according to the Guide for the Care and Use of Laboratory Animals, from the US Department of Health and Human Services, Washington DC, 1985.

\section{Isolation, purification and determination of the chemical structure of iso-6-spectaline}

The botanical material, leaves $(1.5 \mathrm{~kg})$, stem $(5.1 \mathrm{~kg})$ and roots $(3.8 \mathrm{~kg})$, was triturated and exhaustingly extracted with ethanol and concentrated in rotative evaporator, producing $39 \mathrm{~g}, 27.5 \mathrm{~g}$ and 
$42 \mathrm{~g}$ respectively. The leaf extract $(39 \mathrm{~g})$ was then submitted to technical of selective extraction of alkaloids a fraction rich in alkaloids (FA) and a non alkaloids (FNA) one were obtained. The alkaloid fraction was submitted to chromatography on SEPHADEX, with methanol as movable phase. The dichloromethane fraction $(7.6 \mathrm{~g})$ was submitted to the same chromatography process.

The analysis of the fractions was made in chromatography in thin layer (CCD), which revealed the purity of the rich fraction in iso-6-spectaline $(30 \mathrm{mg})$. Its spectra of NMR RMN ${ }^{1} \mathrm{H}, \mathrm{RMN}^{13} \mathrm{C}$, DEPT 135, COSY, HMBC e HSQC ${ }^{1}$ were obtained and compared with the data from the literature for identification. The iso-6-spectaline is amorphous white solid with M.P. 130.8-132.3 ${ }^{\circ} \mathrm{C}$; the value of TLC in $\mathrm{MeOH} / \mathrm{EtOAc}(1: 1), \mathrm{Rf}=0.58$; NMR spectra description of ${ }^{1} \mathrm{H}$ is ${ }^{1} \mathrm{H}$ NMR $(\mathrm{MeOD}, 500 \mathrm{MHz}) \delta_{\mathrm{H}} 3.83(1 \mathrm{H}$, $\mathrm{H}-3)$; $3.30(1 \mathrm{H}, \mathrm{H}-6) ; 3.23(1 \mathrm{H}, \mathrm{H}-2) ; 2.47(2 \mathrm{H}, \mathrm{H}-12) ; 2.15(3 \mathrm{H}, \mathrm{H}-14) ; 1.44(3 \mathrm{H}, \mathrm{H}-7) ; 1.29-1.33(12 \mathrm{H}$, $\mathrm{H}-4-\mathrm{H}-9)$; NMR spectra description of ${ }^{13} \mathrm{C}$ is ${ }^{13} \mathrm{C}$ NMR (MeOD, $\left.125 \mathrm{MHz}\right) \delta_{\mathrm{C}}-212.4(\mathrm{C}, \mathrm{C}-13) ; 66.1(\mathrm{CH}$, C-3); $58.8(\mathrm{CH}, \mathrm{C}-2) ; 57.7(\mathrm{CH}, \mathrm{C}-6) ; 44.4\left(\mathrm{CH}_{2}, \mathrm{C}-12\right)$; $34.9\left(\mathrm{CH}_{2}, \mathrm{C}-1\right)$; $31.2\left(\mathrm{CH}_{2}, \mathrm{C}-4\right) ; 29.9\left(\mathrm{CH}_{3}, \mathrm{C}-\right.$ $14) ; 30.9\left(\mathrm{CH}_{2}, \mathrm{C}-3\right) ; 30.5\left(\mathrm{CH}_{2}, \mathrm{C}-10\right) ; 30.5-30.9\left(\mathrm{CH}_{2}, \mathrm{C}-4-\mathrm{C}-9\right) ; 26.4\left(\mathrm{CH}_{2}, \mathrm{C}-2\right) ; 23.8\left(\mathrm{CH}_{2}, \mathrm{C}-5\right) ; 23.8$ $\left(\mathrm{CH}_{2}, \mathrm{C}-11\right) ; 16.1\left(\mathrm{CH}_{3}, \mathrm{C}-7\right)$. In the present work, the iso-6-spectaline was suspended in $0.5 \%$ Tween 80 distilled in water, and sonicated before use.

\section{Pharmacologic assays for determination of anxiolytic activity}

The open-field arena was made of acrylic (transparent walls and black floor, $30 \times 30 \times 15 \mathrm{~cm}^{3}$ ), divided into nine squares of equal areas. The open-field was used to evaluate the exploratory activity of the animal (ARCHER, 1973). The mouse was placed individually into the center of the arena, and allowed to explore it freely. The parameters observed were: ambulation (the number of squares crossed with all four paws) and numbers of grooming and rearing, recorded during the last $5 \mathrm{~min}$ of the 6 min testing period. In order to elucidate the mechanisms possibly involved with the SPEC sedative effects, we used flumazenil administered alone or associated with SPEC, in the open-field test.

\section{Pharmacologic assays for determination of antidepressant activity}

For assessing antidepressant activities, we employed the procedure that was previously described by (PORSOLT et al., $1977 \mathrm{a}, \mathrm{b}$ ). The development of immobility when mice were placed inside an inescapable cylinder filled with water reflects the cessation of persistent escape-directed behavior (PORSOLT el at., 1978). Briefly, mice had a swimming-stress session for $15 \mathrm{~min}$ (pretest), $24 \mathrm{~h}$ before being individually placed into glass cylinders (height: $25 \mathrm{~cm}$; diameter: $10 \mathrm{~cm}$; containing $10 \mathrm{~cm}$ of water at $24 \pm 1^{\circ} \mathrm{C}$ ) for 5 min (test). A mouse was considered to be immobile when it ceased struggling and remained floating motionless on the water, making only small movements necessary to keep its head above water. Another group of animals was submitted to the forced swimming test. Controls were administered with distilled water. Similarly, in order to clarify the antidepressant effects of SPEC (FERRINI et al., 1974), imipramine and paroxetine alone or in combination with SPEC were used, in the forced swimming test. Imipramine was chosen because it is a classical antidepressant that acts through noradrenergic and serotonergic pathways. Paroxetine, another antidepressant drug, is more selective and acts predominantly through serotonergic pathways. Both antidepressants were then used, alone as positive controls or in combination with the two testing doses of SPEC, in order to investigate any possible alteration or interference of imipramine or paroxetine on the antidepressant effect of SPEC. Reserpine, a drug known to cause depletion of biogenic amines (noradrenaline, dopamine and serotonin) from storage granules, was also used to evaluate the participation of those amines in the SPEC antidepressant effects. In the combination protocol, imipramine, paroxetine or reserpine were administered 30 min before SPEC and the test was performed $1 \mathrm{~h}$ later (OTUKI et al., 2001; HERRERARUIZ et al., 2005).

\section{Statistical analyses}

All data represent mean \pm S.E.M. the values. The data were analyzed by means of analysis of variance (ANOVA) of two routes. Whenever ANOVA was significant, further multiple comparisons were made using test t-Student-Newman-Keuls as the post hoc test. All analyses were performed using the software Prism 3.0 for Windows. The levels of statistical significance ranged from $p<0.05$ to $p<0.001$.

\section{RESULTS}

\section{Results of anxiolytic actions of iso-6-spectaline}

SPEC, at the doses (1.5 and $3.0 \mathrm{mg} / \mathrm{kg}$, i.p.) did not cause sedative effects as assessed by the open-field test (Fig. 1). Significant effects were detected with both doses which produced similar percentages of stimulation (57 and $65 \%$, respectively) in the number of crossings $(p<0.05)$, as compared 
to controls. The number of rearing $(p<0.05)$ and the time spent in grooming behavior $(p<0.05)$ were increased with SPEC 1.5 and $3.0 \mathrm{mg} / \mathrm{kg}$ respectively, whose results were different from to those observed with diazepam, used as a positive control (no. of crossings, rearing, grooming $(p<0.05)$ ). Diazepam reduced the number of crossings, rearing, grooming in $46,63,215 \%$, respectively, $(p<0.005)$ (Fig. 1). Flumazenil was used to evaluate the possible mechanism of action of SPEC sedative effect. For this, 15 $\mathrm{min}$ after the flumazenil injection, SPEC (1.5 and $3.0 \mathrm{mg} / \mathrm{kg})$ was administered. Under these conditions the animals' behavior was similar to the controls, indicating that SPEC does not present a benzodiazepine-type sedative effect. The flumazenil at the doses tested was not able to alter the number of crossings, rearing, grooming in comparison to control and SPC (1.5 and $3.0 \mathrm{mg} / \mathrm{kg}$ ) groups.

(I)
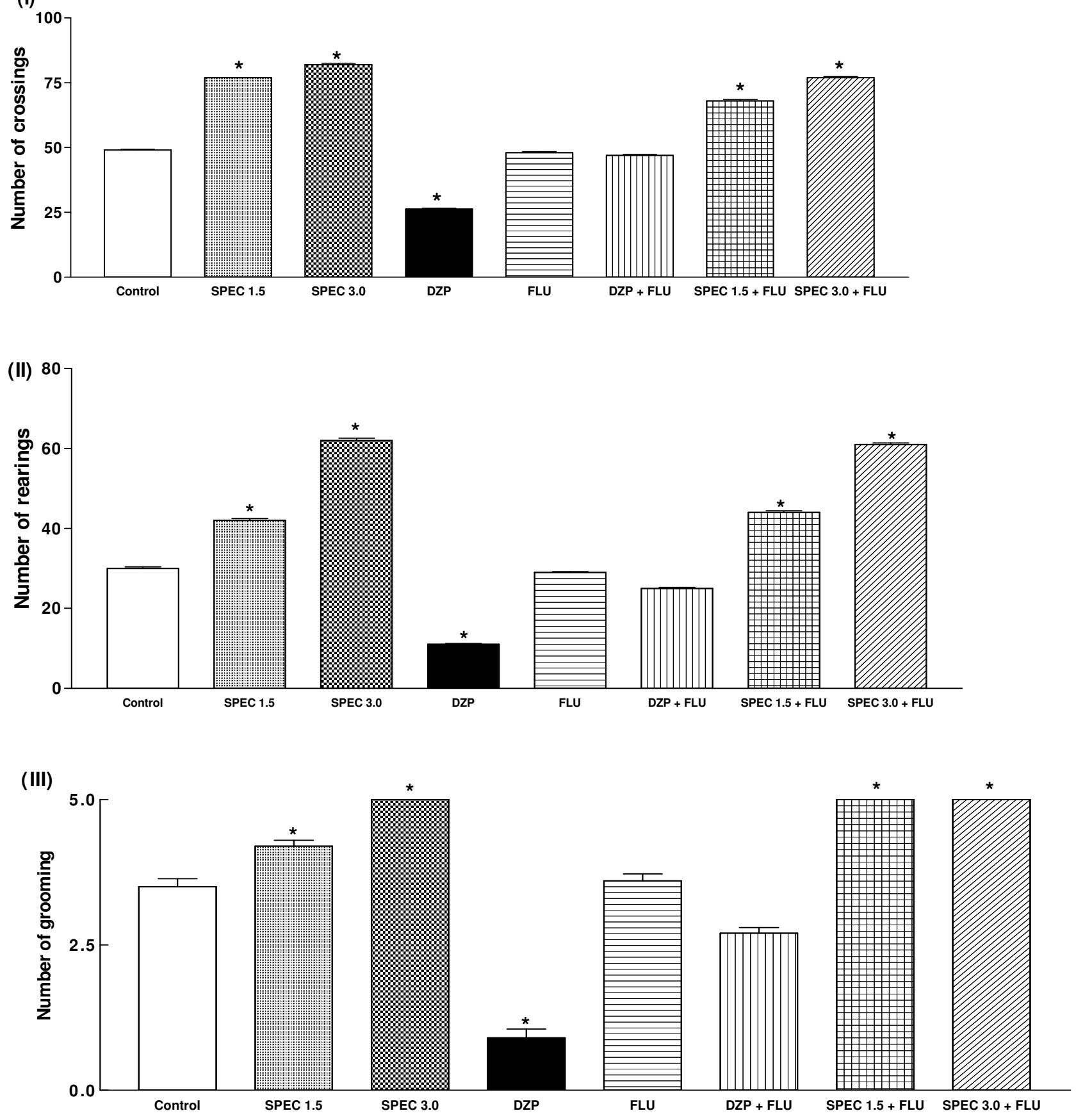
Fig.1. Effects of iso-6-spectaline in adult mice in the open field test.

The effects of iso-6-spectaline (SPEC) in the number of crossings, number of rearing and in the number of grooming are presented in figure.

Control = Tween 0.5\%; SPEC, 1.5 and 3.0 mg/kg, i.p.; DZP - Diazepam, 5mg/kg, i.p.; FLU - flumazenil, 2.5 $\mathrm{mg} / \mathrm{kg}$, i.p.;

Each bars represents the values of mean \pm S.E.M., from 8 animals per group.

${ }^{*} p<0.05$ as compared to controls (ANOVA and test t-Student-Newman-Kewls as the post hoc test).

\section{Results of antidepressant actions of iso-6-spectaline}

The possible antidepressant effect of SPEC after intraperitoneal administration was verified during the forced swimming test (Table 1). Under this condition, SPEC was used at doses (1.5 and $3.0 \mathrm{mg} / \mathrm{kg}$, i.p.). The results have shown that SPEC presents a significant antidepressant effect, at the doses of 1.5 and 3.0 $\mathrm{mg} / \mathrm{kg}$, considering the 37 and $61 \%$, decreases, respectively, in the time of immobility.

The association of SPEC, at the doses $(1.5$ and $3.0 \mathrm{mg} / \mathrm{kg}$ ), with imipramine (IMI) showed a greater decrease of the immobility time $(p<0.05)$, respectively, as related to the groups treated with SPEC alone $(1.5$ and $3.0 \mathrm{mg} / \mathrm{kg}, \mathrm{p}<0.05)$ or IMI $(\mathrm{p}<0.05)$ alone. However, the association of SPEC with paroxetine $(\mathrm{p}<0.05)$ did not alter the effect observed with SPEC or paroxetine alone $(p<0.05)$, respectively, suggesting that the serotonergic system is not involved in the antidepressant effects of SPEC. On the contrary, the SPEC activity was totally blocked by the previous administration of reserpine. These findings suggest that the noradrenergic system participates in the SPEC antidepressant action.

Table 1: Antidepressant effects of iso-6-spectaline in mice in model of forced swimming

\begin{tabular}{lc}
\hline Groups & $\begin{array}{c}\text { Time of immobility } \\
\text { (s) }\end{array}$ \\
\hline Control & $223.4 \pm 2.2(16)$ \\
SPEC $1.5 \mathrm{mg} / \mathrm{kg}$ & $140.74 \pm 2.1^{\mathrm{a}}(8)$ \\
SPEC $3.0 \mathrm{mg} / \mathrm{kg}$ & $87.13 \pm 1.7^{\mathrm{b}}(8)$ \\
IMI $25 \mathrm{mg} / \mathrm{kg}$ & $115.2 \pm 2.5^{\mathrm{a}}(8)$ \\
IMI $50 \mathrm{mg} / \mathrm{kg}$ & $76.9 \pm 1.9^{\mathrm{b}}(8)$ \\
PAROX $10 \mathrm{mg} / \mathrm{kg}$ & $84.9 \pm 1.1^{\mathrm{b}}(8)$ \\
PAROX $20 \mathrm{mg} / \mathrm{kg}$ & $135.2 \pm 2.3^{\mathrm{b}}(8)$ \\
SPEC $1.5+\mathrm{IMI} 50 \mathrm{mg} / \mathrm{kg}$ & $105.2 \pm 2.8^{\mathrm{b}}(8)$ \\
SPEC $3.0+\mathrm{IMI} 50 \mathrm{mg} / \mathrm{kg}$ & $96.9 \pm 1.9^{\mathrm{b}}(8)$ \\
SPEC $3+\mathrm{PAROX} 20 \mathrm{mg} / \mathrm{kg}$ & $125.9 \pm 2.3^{\mathrm{a}}(8)$ \\
RESERP $0.25 \mathrm{mg} / \mathrm{kg}$ & $265.2 \pm 3.8(8)$ \\
RESERP $0.25+$ SPEC $3 \mathrm{mg} / \mathrm{kg}$ & $195.9 \pm 3.8(8)$ \\
\hline
\end{tabular}


Experiments performed as described in materials and methods. SPEC was administered intraperitoneally. Values are means \pm S.E.M. of the immobility time. In parenthesis is the number of animals per group. IMI = imipramine; PAROX = paroxetine; RESERP = reserpine. Drugs were administered $10 \mathrm{~min}$ before SPEC and the test performed 30 min later. ${ }^{a} \mathrm{p}<0.05$ and ${ }^{\mathrm{b}} \mathrm{p}<0.01$ as compared to controls (ANOVA and test t-Student-Newman-Kewls as the post hoc test).

\section{DISCUSSION}

In present work, the effects on central nervous system of the piperidine alkaloid iso-6-spectaline (SPEC) isolated of leaves from Senna spectabilis, were studied. SPEC was firstly evaluated on the open-field test whose results gave any indication of the animal's emotional state. The results showed that SPEC was able to significantly increase not only the number of crossings, but also grooming and rearing. Flumazenil reversed the diazepam effect, but did not reverse the SPEC effect, indicating that both drugs might present different mechanisms of action. The flumazenil was able to antagonize the effects of diazepam by blocking the GABAergic receptors, when various actions associated with SPEC were observed, since it does not reverse the effects of alkaloid suggesting that it has a different mechanism of action.

SPEC was also able to decrease the immobility time of the animals, at the doses of 1.5 and $3.0 \mathrm{mg} / \mathrm{kg}$, in the forced swimming test. At higher doses ( 5 and $10 \mathrm{mg} / \mathrm{kg}$ ), however, the antidepressant effects was masked by sedative and hypnotic actions of the drug (data not shown). The SPEC effects were increased by imipramine, a tricyclic antidepressant (TCA) which blocks the reuptake of both serotonin (5-HT) and of norepinephrine (NE). However, any alteration was seen after SPEC association with paroxetine, a known selective serotonin reuptake inhibitor (PETTY, 1995; PALUCHA and PILE, 2002). Additionally, SPEC effects were totally blocked by the reserpine pretreatment, a known inhibitor of the vesicular catecholamine transporter, which that facilitates vesicular storage. A similar process occurs at storage sites for $5-\mathrm{HT}$, what can finally result in a depletion of biogenic amines. Furthermore, this finding suggests that the possible antidepressant effect of SPEC is probably related, at least in part, to the increase in cerebral noradrenergic activity.

In a recent paper (VIEGAS et al., 2008), piperidine alkaloid from S. spectabilis have been reported by capacity of inhibit the enzymatic activity of AChE, but the effects in 5-HT, NE, amino-y-butyric acid (GABA) and dopamine (DA) contents as well as their cerebral metabolites of rat not yet been demonstrated. The recent preoccupation with the role of serotonin in the treatment of depression has ignored the role of NA, and the fact that these two neurotransmitters act in a manner associated and complex in central nervous system (WHITING, 2006; YILDIZ et al., 2002; WIJEWEERA et al., 2006).

Early evidence (BRUNELLO et al., 2002) of a role for NA in depression came from the discovery that drugs, either causing or alleviating depression, acted to alter the synthesis, metabolism, and/or release of NA. Furthermore, depletion studies carried out in treated and untreated patients indicated a role for serotonin and noradrenaline in depression. A number of relatively selective noradrenaline reuptake inhibitors have been widely used as antidepressant, including desipramine and protriptyline. However, all these drugs are TCA and have a propensity to cause unwanted side effects due to their non-selective interactions with muscarinic, noradrenergic and serotonergic receptors. The efficacy of these drugs is undoubtedly a product of these interactions during the depression.

Our results give support to the idea that SPEC does not interacts with the $\mathrm{GABA}_{\mathrm{A}}$ receptor, probably not with the receptor subtypes that mediate benzodiazepine effects. SPEC does not produce sedative and hypnotic activities in low doses tested; however, it can act to increase the noradrenergic activity which is the main factor responsible for its possible antidepressant activity. Additional studies are needed to fully clarify the SPEC mechanism of antidepressant effects. Furthermore, at different doses, SPEC could present these effects without causing sedative or hypnotic activities. Thus, could be justified their used in clinical practice.

\section{REFERENCES}

ABATAM, M. O. Anote on the antiinflamatory action of plants of some Cassia species. Fitoterapia. v. 4, p. 336-338, 1961.

ARCHER, J. Tests for emotionality in rats and mice: a review. Animal Behaviour. v. 21, p. 205-235, 1973.

AGRA, M. F. Plantas da medicina popular dos Cariris Velhos - Paraíba, Brazil, PNE, João Pessoa, p. 112-115, 1996.

BRINKHAUS, B. et al. Chemical, pharmacological and clinical profile of the East Asian medical plant Centella asiatica. Phytomedicine. v. 7, p. 427-448, 2000.

BRUNELLO, N. et al. The role of noradrenaline and selective noradrenaline reuptake inhibition in depression. European Neuropsychopharmacology. v. 12, p. 461-475, 2002. 
CORREIA, P. Dicionário de planta úteis do Brazil e das exóticas cultivadas. Ministério da Agricultura, Rio de Janeiro, Brazil: Imprensa Nacional, v. 1, p. 82-85, 1984.

COSTA-LOTUFO, L. V. et al. Analgesic, antiinflammatory and central depressor effects of the hydroalcoholic extract and fractions from Aeolanthus suaveolens. Biological \& Pharmaceutical Bulletin. v. 27, p. 821-824, 2004.

DUNHAM, N. W.; MIYA, T. S. A note on a simple apparatus for detecting neurological deficits in rats and mice. Journal of the American Pharmaceutical Association. v. 46, p. 205-208, 1957.

FERRINI, R.; MIRAGOLI, G.; TACCARDI, B. Neuropharmacological studies on SB 5833, a new psychotherapeutic agent of the benzodiazepine class. Arzneimittel-Forschung. v. 24, p. 2029-2032, 1974.

HARVEY, A. L. The pharmacology of galanthamine and its analogues. Pharmacology \& Therapeutics. v. 68, p. 113-128, 1995.

HERRERA-RUIZ, M. et al. Anxiolytic and antidepressant like activity of a standardized extract from Galphimia glauca. Phytomedicine. v. 13, p. 23-28, 2005.

OTUKI, M. F. et al. Evaluation of the antinociceptive action caused by ether fraction and a triterpene isolated from resin of Protium kleinii. Life Sciences. v. 69, p. 2225-2236, 2001.

PALUCHA, A.; PILE, A. On the role of metabotropic glutamate receptors in the mechanisms of action of antidepressants. Polish Journal of Pharmacology. v. 54, p. 581-586, 1995.

PETTY, F. GABA and mood disorders; a brief review and hypothesis. Journal of Affective Disorders. v. 34, p. 275$281,1995$.

PIVATTO, M. et al. Electrospray lonization Mass Spectrometry Screening of Piperidine Alkaloids from Senna spectabilis (Fabaceae) Extracts: Fast Identification of New Constituents and Co-metabolites. Journal of Brazilian Chemical Society. v. 16, p. 1431-1438, 2005.

PORSOLT, R. D.; BERTIN, A.; JALFRE, M. Behavioral despair in mice: a primary screening test for antidepressants. Archives of International Pharmacodynamic and Therapeutics. v. 229, p. 327-336, 1977a.

PORSOLT, R. D. et al. Depression: a new animal model sensitive to antidepressant treatments. Nature. v. 266, p. 730-732, 1977b.

PORSOLT, R. D. et al. Behavioural despair in rats: a new model sensitive to antidepressant treatments. European Journal of Pharmacology. v. 47, p. 379-391, 1978.

SHAHVERDI, A. R. et al. Antimicrobial and cytotoxicity potential of Peganum harmala smoke. Pharmacognosy Magazine. v. 4, p. 236-240, 2008.

VIEGAS, C. Jr. et al. Further Bioactive Piperidine Alkaloids from the Flowers and Green Fruits of Cassia spectabilis. Journal of Natural Products. v. 67, p. 908-910, 2006.

VIEGAS, C. Jr. et al. Antinociceptive profile of 2,3,6-trisubstituted piperidine alkaloids: 3-O-acetyl-spectaline and semi-synthetic derivatives of (-)-spectaline. Chemical \& Pharmaceutical Bulletin. v. 56, p. 407-409, 2008.

WHITING, P. J. GABA-A receptors: a viable target for novel anxiolytics? Current Opinion in Pharmacology. v. 6, p. 24-29, 2006.

WIJEWEERA, P. et al. Evaluation of anxiolytic properties of Gotukola (Centella asiatica) extracts and asiaticoside in rat behavioral models. Phytomedicine. v. 13, p. 9-10, 2006.

YILDIZ, A.; GONUL, A. S.; TAMAM, L. Mechanism of actions of antidepressants: Beyond the receptors. Bulletin of Clinical Psychopharmacology. v. 12, p. 194-200, 2002. 